\title{
Main aspects of system hierarchy in ecological landscape research
}

\section{Abstract}

At present, geoecology-related discussions are focused on the ability to provide systematic and universal landscape description in a variety of space and time scales, as well as in different functional systems. This requires the development of landscape schemes in the form of hierarchical structural and functional systems. This paper has therefore focused on concepts of crucial importance for landscape system description, such as scale, spatial range and structure and landscape functioning. The definition of these concepts and their characteristics are crucial for the ability to describe a landscape system, in terms of its structural and functional composition and valuation, as well as assessment of landscape and ecosystem functions and services. Therefore, the analysis allows a demonstration of approaches discussed in the subject literature and the authors' opinions.

Keywords

Landscape $\bullet$ hierarchical system $\bullet$ landscape structure $\bullet$ scale $\bullet$ landscape dynamics $\cdot$ landscape classification systems

(C) University of Warsaw - Faculty of Geography and Regional Studies

\author{
Andrzej Richling ${ }^{1}$, Jerzy Lechnio ${ }^{2}$ \\ 'Department of Geoecology \\ Institute of Physical Geography \\ Faculty of Geography and Regional Studies \\ University of Warsaw \\ Department of Tourism and Recreation \\ Faculty of Health and Social Sciences \\ Pope John Paul II State School of Higher \\ Education in Biała Podlaska \\ e-mail: a.richling@uw.edu.pl \\ 2Department of Geoecology \\ Institute of Physical Geography \\ Faculty of Geography and Regional Studies \\ University of Warsaw \\ e-mail: jrlechni@uw.edu.p \\ Received: 19 October 2013 \\ Accepted: 5 December 2013
}

Introduction

Geoecology-related discussions have focused on the ability to provide systematic and universal landscape description in a variety of space and time scales, as well as in different functional systems. This requires the development of landscape schemes in the form of hierarchical structural and functional systems (Lechnio, Richling 2005). The complexity of such a system is considered in terms of its functioning and organization (Hay et al. 2002; Müller 1998; Müller et al. 2000; Steinhardt et al. 2003). In such cases, a landscape is treated as a multi-scale system (Wu, David 2002; Wu, Marceau 2002; Kolasa 2006).

The approach focuses not only on structural differentiation of the landscape, depending on the research scale among other things, but also on characteristics and processes treated as predominant, which decide on the complementary structure, dynamics and functional differentiation of the landscape, corresponding to the determined level of the hierarchical landscape system. Such a concept of complex, multi-functional and hierarchical natural systems (Urban et al. 1987; Nicolis, Prigogine 1989) refers to the general theory of systems (von Bertalanffy 1976).

From the hierarchical viewpoint, a landscape is therefore a system that can be characterized by any number of co-existing components and their characteristics or processes, and whose form is the result of the non-linear, adapting impact of spatial and time components (King 1991).

The macroscopic (observable) scale of landscape processes occurring in the form of spatial structures and time sequences is crucial for their recognition (Nicolis, Prigogine 1989).

Recognition of landscape structure is therefore the key step towards evaluating the processes that resulted in its existence. Their relationship in turn provides the necessary basis on which to separate functional schemes within a landscape system. Thus, a holistic landscape description must include its organizational hierarchy, i.e. the system of its subordinate components (units subsystems) and their potential, and type of functions (services), i.e. broadly defined value. It should be noted that these features may be identified with geo- and biodiversity treated both as general environmental characteristics and those understood as the target status of environmental changes, environmental system functioning and its functions or ecosystem services (Benito-Calvo et al. 2009; Corenblit et al. 2011; Kostrzewski 2011; Kozłowski 2004; Kozłowski et al. 2004; Leser 1998; Lindenmayer et al. 2008; Richling, Solon 2011; Turner 1989; Walz 2011).

In light of the above it is important to note, as stressed by Hearnshaw et al. (2012), that in certain cases dynamic systems must be analysed as objects that cannot be decomposed (Wolfram, 1984).

Certain characteristics of individual ecosystems may be disclosed only on the general level, assessing the system as a whole, since this is the only perspective allowing a conclusion of their nature and functional relationship with the environment. Reductionism in the approach to research and analysing each component separately disallows the disclosure of features visible only on the holistic analysis level (Naveh, 2001).

Therefore, concepts such as scale, spatial range and structure, as well as mode of functioning, are crucial for the description of landscape systems. Defining these concepts and their characteristics determines the ability to describe a landscape system, in terms of its structural and functional composition and valuation, as well as assessment of landscape and ecosystem functions and services. 
Scale and scaling as factors implying the hierarchical nature of landscape

The assessment of any (physical) system or process may be either quantitative or qualitative. Qualitative assessment refers to the system structure and is relative, depending on the nature of the elements included to valuation and their spatial and functional relations. Quantitative assessment requires the use of a specified benchmark.

In natural sciences, the scale is the basic tool used to express spatial characteristics of surveyed systems. The scale defines material dimensions of a given object, phenomenon, process or observation (feature) in relation to space, time or function (Cushman et al. 2002; Dungan et al. 2002; Garrett et al. 1997; Levin 1992; Peterson 2000; Peterson \& Parker 1998, Schneider 2001; Wiens 1989; Wu 2000).

Therefore, the scale acts as a template or a filter, and thus should be perceived and measured along with the system, since it determines the benchmark for measurements and observations performed (Hay et al. 2002; Manson 2008; O'Neill, King 1998; Schneider 2001; Steele 1991; Wiens 1989). This is crucial for understanding and interpreting surveyed structures, since the scale underlies the attribute perception level (Hay et al. 2002; Marceau 1999).

In landscape ecology, the scale is usually defined in a disjunctive manner, i.e. in relation to the size of grains (units) corresponding to the basic spatial separation: resolution or the extent of the survey. Any scale change results in a change in resolution or range, or both (Turner 1989).

Additionally, Schneider et al. (1994) has noticed that the system structure (understood as its tangible components) has spatial range determined (or determinable) for a given scale, while endogenous processes, although dependent on structural characteristics, are individual by nature and do not need to relate closely to the range of each component. This includes both the distance marked by individual processes and the potential or actual scope of their impact. Following such an approach, size, shape, distance and area are crucial components of the ecological scale (Norowi 2000). According to Levin (1992), no fixed and unambiguous natural scale exists, since natural systems differ materially in terms of spatial features, dynamics and organization. The scale of observation depends on the benchmark system adopted (convention, norm) and is characterized by the following components:

- survey range, area or period (duration);

- resolution;

- weight of measurement or a time constant (interval).

According to the presented approach, we can also refer to the "characteristic process scale" defining process range and/or duration, i.e. time during which a surveyed process may occur in the form of measurable system changes and responses. Mutual alignment of the observation scale, range and pace (or scale) of surveyed processes is of key importance for the scope of the permitted characteristics of ecosystems and the accuracy of conclusions drawn on this basis (Millennium Ecosystem Assessment, 2003).

In this approach, the scale corresponds to spatial aspects of landscape system organization. Moreover, hierarchical levels of such systems may be considered using a scale (Allen, Star 1992), since each separated functional level may be treated as a part of a bigger whole (Powell 2000).

In this case, internal uniformity of the key (smallest) spatial units, not necessarily identified with resolution, but considered as internal homogeneity of such objects, corresponding to the scale (weight) of descriptive characteristics, is of crucial importance.
The descriptive characteristics of ecosystems may be classified as independent of the scale, depending on the scale according to the adopted scalability rules, or not classified as scalable.

"Defining" the scale (the "characteristic process scale") prior to observation and measurement is the best solution to guarantee high reliability of data (Wheatley, Johnson 2009), which should be accompanied by an identification of the temporal and spatial hierarchy of landscape processes (according to their dynamics: from short- to long-duration and spatial range: from small to large). In such cases, data scaling involves bottom-up (generalizing) or top-down transposition (increasing the level of detail), adequate to the temporal, spatial or functional organization of the landscape system according to each hierarchical level of landscape classification (Auger, Lett 2003; Bugmann et al. 2000; King 1991; Melbourne, Chesson 2005; Wu 1999, 2004).

Defined in such a manner, the scaling of data, the hierarchical nature of the landscape system is of crucial importance to understanding and forecasting complex ecological processes. From the perspective of landscape system assessment, the "scale" determines the range of the survey. Therefore, correct and reliable monitoring, modelling and management of such systems require multi-scale and hierarchical solutions (Müller et al. 2011). This is especially important for surveying of biophysical phenomena and processes which are too large / too small in terms of structure and (or) dynamics, or too fast / too slow to allow direct observation.

With reference to the above, the problem of scale and the related aspect of data scaling (transposing) in natural sciences requires two complementary questions to be answered (Marceau, Hay 1999; Marceau, 1999):

- Which spatial scale is suitable for researching a defined object or process with geographical relationships?

- How should inter-scale data transfer proceed?

According to Wiens (1995), "natural processes do not determine scale themselves", but the landscape scale is not its immanent feature, either, being a result of the sampling methodology adopted (Allen, Hoekstra 1992). Additionally, such systems may be considered as "self-organizing systems" or "complex adaptation systems" whose dynamics and evolving features are the result of the interaction of heterogeneous elements in various temporal and spatial scales (O'Neill et al. 1986). Therefore, determining the governing rules that may be characterized by a set of inseparable features is the only possible way to describe such systems. In geoecology, decomposing such systems may take place in accordance with the theory of hierarchical systems (O'Neill et al. 1986), which allows their bottom-up and top-down analysis from the viewpoint of subsystems and vertical relationships ( $\mathrm{Wu}$, David 2002). Therefore, according to the theory of landscape science, the concept of scale may be considered in relation to three aspects (Dungan et al. 2002; Müller et al. 2011): observation, the scale's ontological meaning and representative character. In the first case, the scale represents the concept of a perception filter (window) allowing quantitative assessment of landscape features (Hay et al., 2002). Thus, it does not constitute a characteristic of the surveyed system, being dependent on the manner of observation and measurement, an adopted convention (Allen, Hoekstra 1992). The ontological approach refers to the concept of characteristic scale (of an object, process, phenomenon), to include "effective" size or another measure of the object, or its characteristics and attributes (Marceau 1999). The representative character in turn means scalability of measures, i.e. transposing them among scales (levels) within the landscape system rather than the meaning (weight) of observation as such (Blaschke, Petch 1999). 
Table 1. Systems of dividing landscape into spatial units (according to Chmielewski, 2008)

\begin{tabular}{|c|c|c|c|c|c|}
\hline \multirow{2}{*}{$\begin{array}{l}\text { Landscape } \\
\text { space } \\
\text { classification } \\
\text { levels }\end{array}$} & \multicolumn{5}{|c|}{ Discipline } \\
\hline & Geography & Phytosociology & General ecology & Landscape ecology & Landscape architecture \\
\hline Basic & facies & plant community & \multirow[t]{2}{*}{ ecosystem } & landscape patch & \\
\hline 2 & $\begin{array}{l}\text { natural landmark } \\
\text { (urotshistshe) }\end{array}$ & plant community & & $\begin{array}{c}\text { natural/ landscape } \\
\text { unit }\end{array}$ & $\begin{array}{l}\text { architectonic and } \\
\text { landscape interior }\end{array}$ \\
\hline 3 & field & $\begin{array}{l}\text { vegetation micro- } \\
\text { landscape }\end{array}$ & physiocenosis & physiocenosis & $\begin{array}{l}\text { architectonic and } \\
\text { landscape unit }\end{array}$ \\
\hline 4 & microregion & & & & \\
\hline $\begin{array}{c}\text { physio- } \\
\text { geographical }\end{array}$ & $\begin{array}{c}\text { landscape } \\
\text { phytocomplex }\end{array}$ & & $\begin{array}{c}\text { landscape } \\
\text { complex of } \\
\text { physiocenoses }\end{array}$ & $\begin{array}{l}\text { architectonic and } \\
\text { landscape zone }\end{array}$ & \\
\hline 5 & $\begin{array}{c}\text { physio- } \\
\text { geographical } \\
\text { mesoregion }\end{array}$ & $\begin{array}{l}\text { vegetation } \\
\text { landscape }\end{array}$ & & landscape & landscape \\
\hline 6 & $\begin{array}{c}\text { physio- } \\
\text { geographical } \\
\text { macroregion }\end{array}$ & & & & \\
\hline
\end{tabular}

Structure as a way to express the hierarchical nature of a landscape

Since the scale implies the level of detail perception, and landscape as a system should be analysed in accordance with a number of criteria, its structure may be identified through components and/or processes analysed on various levels, from the viewpoint of structural and functional systems, including those specific to them (since each system has its inherent characteristics which can best be used for its description). Theoretically, such a broad assumption allows differentiation of various spatial unit types and their classification for determined, ontologically consistent levels or hierarchical systems. In practice, though, as noticed by Walz (2011), landscape structure is usually treated as a system (pattern, composition, configuration) of its elements (patches and corridors) that characterize land cover (pattern). Thus, it is described in terms of shape, size, relation and distribution, i.e. characteristics regarding horizontal structures. This "standard" approach to landscape structure evaluation basically covers the entire scope of professional issues. Despite the many possible number of ways to define the concept, they can be grouped into two main streams: structural, relating to mosaic nature (geocomplexes) and functional, in the form of ecosystems (patches and corridors). Under the first model, the structure concerns mainly the relation of landscape units (most frequently, partial geocomplexes), although it may be described through single elements. This does not mean, however, as exemplified by reference to the definition of geocomplex (Barsch 1979; Kondracki, Richling 1983), that the "relationships" may be of functional nature as well, although the problem of complementary range of structural units and processes (the characteristic process scale, the basic field problem) must be decided first.

Under the second approach, landscape structure represents spatial relations between ecosystems, including distribution of ecosystems, species, energy and matter. This concept, therefore, refers directly to the theory of functional systems and the patch and corridor model (Forman and Godron 1986).
Regardless of the possible outcome of the different ways to define the landscape structure, geoecology focuses mainly on indicating optimized opportunities to describe interactions between spatial landscape units and determining their impact on transformation of both structure and function of the system in time. With regard to landscape structure, it implies the following:

- methods and criteria of spatial unit delimitation vs. hierarchical nature of the landscape system;

- the universal landscape unit problem;

- landscape structure vs. existence and nature of landscape barriers and borders;

- landscape classification vs. applicable data scaling methods;

- landscape structure and change rapidity assessment methods;

- relationship of structure and processes to the landscape.

According to the most general approach, classification involves separating a set of objects into sub-sets according to clear criteria (Solon 2009). The use of a conceptual model is therefore involved in order to group landscape components into categories and/or into classes depending on the number and distribution of their characteristics.

The aforementioned process results in generalized information regarding the set of structural attributes and the corresponding functional characteristics and processes. Therefore, the choice of classification criteria, including procedural models and schemes, is of importance (Farina 2000; Fischer et al. 2004; Forman 1995; McIntyre, Hobbs 1999; Manning et al. 2004; O'Neill 1986; Richling 1993, 2004; Richling, Lechnio 2005; Richling, Solon 2011; Solon 2009). It should be noted, however, that such classifications are usually "typical" for specific disciplines and applications (Table 1, Chmielewski 2008).

Natural sciences apply two classification methods: typological (similarity based) and regional (differentiation based). Separating smaller units, referred to in geographical science as 
facies and natural landmarks (urotshistshe) requires fieldwork, while larger units are either a product of combining typological units, or dividing large areas into smaller regions based on predetermined characteristics (Richling 1993).

The arguments and examples derived from the extensive literature on the subject prove that there is no one universal landscape classification procedure. The underlying reasons include:

- Landscape changing rapidly, therefore allowing description through structural characteristics and processes;

- Classification resulting in a general landscape image, with structural characteristics usually correct, while relations between processes and units are presented with less detail and not always accurately;

- Landscape may be perceived in various manners, depending on the discipline, as proven by differences in methodologies and procedures;

- The same space may be differently classified depending on the nature of the problem or survey objective;

- The durable and fixed nature of landscape components underlying the classification determine the fixed and unchangeable nature of separation, in terms of differentiating factors, spatial range and diagnostic variables.

Developing a unified, universal typological landscape classification is difficult, mostly because it is always subordinated to specific objectives (Marušic 1999). Nevertheless, based on the geocomplex concept of Barsch (1979), the controversy lies in the correct documentation of landscape units (geocomplexes), not in their objective existence. In other words, we may discuss only landscape units whose reliability has been proven with specific, reliable data (Pietrzak 2009).

The aforementioned comments do not sufficiently explain the methodological and practical issues regarding process scaling under defined classification systems, including hierarchical ones. This concerns mainly reactions and relations between processes and phenomena in the micro- and macro-scale, as well as their short- and long-time effects referring to various levels of landscape system organization (Gibson et al. 2000; Wilbanks, Kates 1999). In the first case, the type of analysed processes, with special focus on their dependence or independence of scale, is crucial. It is worth noting that structural changes should be analysed first of all in relation to spatial units and their borders, while changes in functioning should be analysed in relation to internal differentiation between landscape mosaic patches (Papadimitriou 2002; Marušič 1999; Victorov 1998). The second case is usually founded on an assumption that the temporal and spatial process scales are correlated (Steinhardt, Volk 2003) and determine the "process domain scale" (Bisonette 1997). Such a relation, for example for processes subordinated to the energy and mass preservation principle, allows the forecasting of longterm effects within the landscape structure through the analysis of the functional spatial system and configuration of landscape patches. This is only possible, however, for a sufficiently large survey scale, since its increase is accompanied by a growth in probability that the full range of events recording the stages (effects) of the changes and impact will occur.

This is especially important for processes slow enough to disallow their measurement. Such a procedure is addressed as "time for space substitution" (Pickett 1989). Therefore, the evaluation of structural characteristics, including patch composition and configuration, both in terms of spatial relations and the possible functional and diagnostic effects, is a key aspect of landscape survey. Most frequently, such analyses are combined with the evaluation of spatial relations between elements, components and landscapes (Wu, David 2002; Turner 2005), diversity (bioand geodiversity), connectedness, fragmentation, anisotropy and many others, as well as with the assessment of temporal changes in the landscape structure (Pickup et al. 1993; Aaviksoo 1995; Fjellstad, Dramstad 1999). For this purpose, landscape metrics and indicators, i.e. measures based on information theory and fractal geometry, are used (McGarigal, Marks 1994; O'Neill et al. 1988).

The spatial structure of a landscape is determined by metrics related to its configuration and composition (shape, spatial distribution, isolation, distance, contrast, relation, share and number of types, even distribution and many others). The analysis of structural characteristics is reflected in the evaluation of bio- and geodiversity, distribution of habitats (ecosystems), structural heterogeneity, as well as the aesthetic aspects of the landscape, evaluation of spatial planning and management effects and, indirectly, the nature of landscape functions and services.

Functional assessment mainly involves surveying a series of observations in time and assessing landscape mosaic changes (Uuemaa et al. 2009; McGarigal et al. 2009; Solon 2002), although attempts are being made to improve diagnostic values of the existing methods (Ares et al. 2001; Uuemaa et al. 2005; Mander et al. 2005). Other solutions involve the construction of models that comprise various aspects of analysis and assessment of the operation, functions and services of landscape systems referring to basic typological units (Tallis et al. 2013).

Importantly, the use of landscape indicators and metrics depends on a number of key aspects, including the resolution of the analysed image, format of data used, choosing the optimum number and type of metrics, their correct informational connotation, adjusting evaluation of the analysed structural characteristics and functional aspects to the landscape systematics applied or the spatial range of analysis. The broad use of automated indicator-based methods disallows a full explanation of the impact made by various scales on the evaluation results, of their incomparability in various scales, application of limited data sets (quite often restricted to the form of composed raster layers), or the issue of relations between metrics and their classes, which needs further analysis.

\section{Landscape barriers and borders}

The issue of barriers and the related border effects is often ignored in discussions regarding landscape structure. Most authors focus on surface analysis only, whereas the definition of borders is of crucial importance, as it determines the definition of a unit, its size, structure and dynamics. The manner of determining the border therefore shapes spatial and functional relations in the landscape system. In light of the above, the question of border determining principles within spatially diverse landscape systems is fundamental to geoecological survey (Bailey 1987).

Linear borders seldom occur in nature. Transitional zones, i.e. ecotones characterized by higher diversity and dynamics than the neighbouring units, prevail. According to common opinion (compare Richling, Solon 2011), border zones should be treated as separate units (geosystems), since they can and should be surveyed, both for their structural and functional characteristics, and since their nature depends on the scale and taxonomic level of a unit (Yarrow, Salthe 2008). Depending on the level within a system, borders are characterized by structural complexity and a defined process speed. Different characteristics and processes in border zones may result in the accumulation or disappearance of functional flows and relations, as well as the multiplication of structural features (Cadenasso et al. 2003a, b).

Borders should be treated as an expression of the internal structure of a landscape system and its internal processes. Depending on the hierarchy level in the landscape system, 
borders are characterized by structural complexity and process speed. Therefore, landscape borders may be treated as: 1) transition zones characterized by more diversity and changes than the neighbouring units; 2) locations where barriers or border zones occur, outstanding in terms of features and processes, which may imply the accumulation or disappearance of functional flows and relations and the multiplication of structural features (Cadenasso et al. 2003a; Peters et al. 2006). Consequently, the border types and functions may be indicated as:

- filters, barriers, corridors, resource or disappearance zones, or habitats (Forman, Moore 1992);

- locations where signals are transmitted (including partial transmission), absorbed, returned, enhanced or neutral by function (Lechnio, Richling 2005; Strayer et al. 2003);

- permeability, stability, flexibility, response to incentives and interruptions (Hansen, di Castri 1992).

Therefore, borders can be functionally subordinated through their relation with surface, ecological functions or thermodynamic gradients (Allen, Starr 1982; Strayer et al. 2003; Kolasa, Zalewski 1995; Múller 1998). Such a perception of borders refers directly to the hierarchical landscape concept and their classification systems. The scope of interpreting landscape features and border functions depends on the resolution and scope of the information characteristic of the landscape, resulting from the landscape system and subsystem (levels) delimitation method applied; thus, it is determined by the scale.

From this viewpoint, in accordance with the functional concept of the landscape system, borders can be considered to be hierarchical sets of features corresponding to individual organization levels of the landscape system (Peters et al. 2006). Such an approach to the problem is offered, among others, by Wu's HPDM model (1999), which treats the landscape system as a combination of spatially defined and hierarchically interrelated units (subsystems). In this model, borders are allocated (scaled) to a defined organization level (through units assigned to a defined hierarchy level) and in later stages can be grouped (ranked) adequately to subsequent system levels - units in the landscape system hierarchy (Wu 1999; Wu, Dawid 2002). This does not limit the occurrence of borders to ecosystem dividers representing the same organizational level and scale (Yarrow, Salthe 2008).

Finally, it should be noted that landscape units with their related borders should not be analysed only for their grouping properties underlying the classification of hierarchical levels; the analysis should also include characteristics that allow the detection of landscape discontinuity. This issue is closely related to the scale of proceeding. A detailed scale, as discussed above, allows the separation of borders as individual units. Thermodynamic processes and "out of scale" features of the defined system levels allow simultaneous analysis of gradients and flow, disclosing exogenous functional relationships and indicating contact between landscape system levels.

\section{Landscape changes and functioning}

Landscape changes are usually considered in relation to landscape structure. Surveys focusing on processes that occur where biotic and abiotic elements connect are much less frequent. In particular, the absence of solutions based on the model description of processes analysed from the biophysical, geochemical, thermodynamic or system theory perspective is perceptible. When discussing the issue, the following aspects need attention:

1. The multi-level structure of the landscape system necessitates its analysis in a broad range of spatial scales referring to processes of different speed. Therefore, various system levels have specific features and respond differently to determined steering factors (McConnell 2002);

2. A change in the scale usually means a change in the relationship between structure and processes (Lindenmayer et al. 2008);

3. "Closed" and "open" systems may alter in nature along with changes of scale;

4. Landscape system units do not operate in isolation. "Open" systems ensure the flow of exogenous matter, energy and information. The speed and size of transfer allows impact transmission to neighbouring levels, thus providing its broad scope; therefore, surrounding conditions are of key importance (Lechnio, Richling 2005). On the other hand, "closed" systems mean that the transfer speed is close to zero, or its speed difference at the contact point of the neighbouring units is so great that they are functionally disconnected. In such cases, the surrounding conditions are not important.

According to the general system theory, landscape changes are analysed in space and time as a result of complex, nonlinear interactions of biotic and abiotic components of the natural system, self-regulation processes, endogenous and exogenous impacts (Allen, Start 1982; O'Neill et al. 1986). The scope of the impacts may achieve a similar value, consequently allowing the separation of defined ranges or levels (O'Neill et al. 1986), which may then be grouped.

In the context of the hierarchical system theory, landscape changes may be analysed both vertically, i.e. in relation to defined scale ranges and landscape system levels (bottom-up and top-down) and horizontally, on each level.

Hierarchical decomposition of a landscape, including the opportunity to act on the basic level of the system using units identified with homogenous structures, allows the analysis of these structures as "integrated flow systems". This method of turning actual systems into schemes allows the analysis of impacts in landscape border zones, which are treated as linear objects according to the model (Wu, David 2002).

With reference to a landscape and its hierarchical structure, this approach allows the consideration of the pace of changes in biotic and abiotic components on the substance and/or energy flow level. Thus, it offers a different quality and broader context to analyse the changes than the traditional approach to ecological system organization levels (population<community<ecosystem <landscape), which seems to be insufficient, e.g. to assess biodiversity, since it does not include the full scope of spatial relations arising from the scale and range (Turner et al. 1995).

\section{Conclusion}

Treating a landscape as a hierarchical system is of crucial importance for the description and explanation of its dynamics and for defining its potential and functions. Analysis of the influence between different functional landscape levels is especially important, with the scale as the key, since it allows an explanation of the basic relations between the structure and processes. Initial assumptions regarding the scale and their effects on the explanation of ecosystem structure and processes determine the reliability of the description of hierarchical landscape structures.

\section{Acknowledgement}

The paper was prepared under the research project of the Ministry of Science and Higher Education - project number $\mathrm{N}$ N305 322135 "Hierarchical model of the natural system and its use for geo- and biodiversity assessment and forecasting." 


\section{References}

Aaviksoo, K 1995, 'Simulating vegetation dynamics and land use in a mire landscape using a Markov model', Landscape and Urban Planning, vol. 31, no. 1, pp. 129-142.

Allen, TFH \& Hoekstra, TW 1992, Toward a unified ecology, Columbia University Press, New York.

Allen, TFH \& Starr, TB 1982, Hierarchy: perspectives for ecological complexity, University Press, Chicago, London.

Ares, J., Bertiller, M \& del Valle, H 2001, 'Functional and structural landscape indicators of intensification, resilience and resistance in agroecosystems in southern Argentina based on remotely sensed data', Landscape Ecol., vol. 16, no. 3, pp. 221-234.

Auger, P \& Lett, C 2003, 'Integrative biology: linking levels of organization', Comptes Rendus Biologie, vol. 326, no. 5, pp. 517-522.

Barsch, H 1979, 'W sprawie pojęć dotyczących powłoki ziemskiej i jej przestrzennego rozczłonkowania w terminologii nauki o krajobrazie' [On the concepts of the Earth surface and its spatial fragmentation in the terminology of the landscape science], Przegląd Zagranicznej Literatury Geograficznej, vol. 2, pp. 9-15.

Bailey, RG 1987, 'Suggested hierarchy of criteria for multiscale ecosystem mapping', Landscape and Urban Planning, vol.14, pp. 313-319.

Benito-Calvo, A, Pérez-González, A, Magri, O \& Meza, P 2009, 'Assessing regional geodiversity: the Iberian Peninsula', Earth Surf. Process. Landforms, vol. 34, pp. 1433-1445.

Bertalanffy von, L 1976, General system theory: foundations, development, applications, (Pub) George Braziller.

Bissonette, JA, 1997, 'Scale-sensitive ecological properties: historical context, current meaning' in Wildlife and landscape ecology: effects of pattern and scale, ed JA Bissonette, Springer-Verlag, New York, USA, pp. 3-15.

Blaschke, T \& Petch, J 1999, 'Landscape structure and scale: comparative studies on some landscape indices in Germany and the UK' in Heterogeneity in landscape ecology: pattern and scale eds M Maudsley \& J Marshall, IALE UK, Bristol, pp. $75-84$.

Bugmann, H, Lindner, M, Lasch, P, Flechsig, M, Ebert, B \& Cramer, W 2000, 'Scaling issues in forest succession modelling', Climatic Change, vol. 44, no. 3, pp. 265-289.

Cadenasso, ML, Pickett, STA, Weathers, KC, Bell, SS, Benning, TL, Carreir, MM \& Dawson, TE 2003a, 'An interdisciplinary and synthetic approach to ecological boundaries', BioScience, vol. 53, pp. 717-722.

Cadenasso, ML, Pickett, STA, Weathers, KC \& Jones, CG 2003b, 'A framework for a theory of ecological boundaries', BioScience, vol. 53, pp. 750-758.

Chmielewski, T 2008, 'Zmierzając ku ogólnej teorii systemów krajobrazowych' [Towards a general theory of landscape systems], The Problems of Landscape Ecology, vol. 21, pp. 93-108.

Corenblit, D, Baas, ACW, Bornette, G, Darrozes, J, Delmotte, S, Francis, RA, Gurnell, AM, Julien, F, Niman, RJ \& Steiger, J 2011, 'Feedbacks between geomorphology and biota controlling Earth surface processes and landforms: A review of foundation concepts and current understandings', Earth Science Reviews, vol. 106, pp. 307-331.

Cushman, SA \& McGarigal, K 2002, 'Hierarchical, multi-scale decomposition of species-environment relationships', Landscape Ecol., vol. 17, pp. 637-646.

Dungan, JL, Perry, JN, Dale, MRT, Legendre, P, Citron-Pousty, S, Fortin, MJ, Jakomulska, A, Miriti, M \& Rosenberg, MS 2002, 'A balanced view of scale in spatial statistical analysis', Ecography, vol. 25, pp. 626-640.
Farina, A 2000, Landscape ecology in action, Springer, pp. 317.

Fjellstad, WJ \& Dramstad, WE, 1999. 'Patterns of change in two contrasting Norwegian agricultural landscapes', Landscape Urban, vol. 45, no. 4, pp. 177-191.

Fischer, J, Lindenmayer, DB, Fazey, I 2004, 'Appreciating ecological complexity: habitat contours as a conceptual landscape model', Conserv. Biol., vol. 18, pp. 1245-1253.

Forman, RTT \& Godron, M 1986, Landscape Ecology, John Wiley and Sons, Inc., New York, USA.

Forman, RTT \& Moore, PN 1992, 'Theoretical foundations for understanding boundaries in landscape mosaics', in Landscape Boundaries, eds AJ Hansen \& F di Castri, Ecological Studies, vol. 92, Springer, New York, pp. 236-258.

Forman, RTT 1995, Land Mosaics: The Ecology of Landscapes and Regions, Cambridge University Press, New York.

Garrett, KA \& Dixon, PM 1997, 'Environmental pseudointeraction: the effects of ignoring the scale of environmental heterogeneity in competition studies', Theor. Popul. Biol., vol. 51, pp. 37-48.

Gibson, CC, Ostrom, E \& Ahn, TK 2000, 'The concept of scale and the human dimensions of global change: a survey', Ecological Economics, vol. 32, pp. 217-239.

Hansen, AJ \& di Castri, F (eds) 1992, Landscape boundaries. Consequences for biotic diversity and ecological flows, Springer-Verlag, New York.

Hay, GJ, Dubé, P, Bouchard, A \& Marceau, DJ 2002, 'A scalespace primer for exploring and quantifying complex landscapes', Ecological Modelling, vol. 153, pp. 27-49.

Hearnshaw, EJS, Cullen, R \& Hughey, KFD, An ecological concept determined by economic means. Commerce division, Lincoln University, environment, society and design division, Lincoln University. Available from: <http://www.een. anu.edu.au/e05prpap/hearnshaw.doc> [2012.04.02].

King, AW 1991, 'Translating models across scales in the landscape', in Quantitative methods in landscape ecology: the analysis and interpretation of landscape heterogeneity, eds MG Turner \& RH Gardner, Springer, vol. 82, New York, pp. 470-517.

Kolasa, J 2006, 'A community ecology perspective on variability in complex systems: The effects of hierarchy and integration', Ecological Complexity, vol. 3, pp. 71-79.

Kolasa, J \& Zalewski, M 1995, 'Notes on ecotone attributes and functions', Hydrobiologia, vol. 303, pp. 1-7.

Kondracki, J \& Richling, A 1983, 'Próba uporządkowania terminologii w zakresie geografii fizycznej kompleksowej' [An attempt to organize the terms in comprehensive physical geography], Przegl. Geogr. vol. 55, no. 1.

Kostrzewski, A 2011, 'The role of relief geodiversity in geomorphology', Geographica Polonica, vol. 84, Spatial Issue, part 2, pp. 60-74.

Kozłowski, S 2004, 'Geodiversity. The concept and scope of geodiversity', Przegl. Geol., vol. 52, no.8/2.

Kozłowski, S, Migaszewski, Z \& Gałuszka, A 2004, 'Znaczenie georóżnorodności w holistycznej wizji przyrody' [The importance of geodiversity in the holistic vision of nature], Przegl. Geol., vol. 52, no. 4.

Lechnio, J \& Richling, A 2005, 'Model funkcjonowania krajobrazu - ocena dynamiki z zastosowaniem analizy przepływów' [Model of the landscape functioning - evaluation of dynamics using flow analysis] in Z Problematyki Funkcjonowania Krajobrazów Nizinnych [On the problems of functioning of the lowland landscapes], eds A Richling \& J Lechnio, WGSR UW, Warszawa.

Leser, H \& Nagel, P 1998, 'Landscape diversity - a holistic approach' in Biodiversity. A Challenge for Development 
Research and Policy, eds W Barthloff \& M Wininger, Berlin Heidelberg - New York.

Levin, SA 1992, 'The problem of pattern and scale in ecology', Ecology, vol. 73, pp. 1943-1967.

Lindenmayer, D, Hobbs, RJ, Montague-Drake, R, Alexandra, J, Bennett, A, Burgman, M, Cale, P, Calhoun, A, Cramer, V, Cullen, P, Driscoll, D, Fahrig, L, Fischer, J, Franklin, J, Haila, Y, Hunter, M, Gibbons, P, Lake, S, Luck, G, MacGregor, C, McIntyre, S, Nally, RM, Manning, A, Miller, J, Mooney, H, Noss, R, Possingham, H, Saunders, D, Schmiegelow, F, Scott, M, Simberloff, D, Sisk, T, Tabor, G, Walker, B, Wiens, J, Woinarski, J \& Zavaleta, E 2008, 'A checklist for ecological management of landscapes for conservation', Ecology Letters, vol. 11, pp. 78-91.

Mander, Ü, Müller, F \& Wrbka, T 2005, 'Functional and structural landscape indicators: Upscaling and downscaling problems', Ecological Indicators, vol. 5, pp. 267-272.

Manning, AD, Lindenmayer, DB \& Nix, HA 2004, 'Continua and umwelt: novel perspectives on viewing landscapes', Oikos, vol. 104, pp. 621-628.

Manson, SM 2008, 'Does scale exist? An epistemological scale continuum for complex human-environment systems', Geoforum, vol. 39, pp. 776-788.

Marceau, D 1999, 'The scale issue in social and natural sciences', Can. J. Remote Sensing, vol. 25, pp. 347-356.

Marceau, DJ \& Hay, GJ 1999 'Contributions of remote sensing to the scale issues', Canadian Journal of Remote Sensing, vol. 25, pp. 357-366.

Marušič, J 1999, 'Landscape typology as a basis for landscape protection and development', Agriculturae Conseptus Stientificus, vol. 64, no. 4, pp. 269-274.

McConnell, W 2002, 'Meeting in the middle: The challenge of meso-level integration', LUCC Report Series No. 5, Land Use Policy, vol. 19, pp. 99-101.

McGarigal, K \& Marks, BJ 1995, FRAGSTATS: spatial pattern analysis program for quantifying landscape structure, USDA For. Serv. Gen. Tech. Rep. PNW.

McGarigal, K, Tagil, S \& Cushman, SA 2009, 'Surface metrics: An alternative to patch metrics for the quantification of landscape structure', Landscape Ecology, vol. 24, pp. 433450.

Mclntyre, S \& Hobbs, R 1999, 'A framework for conceptualizing human effects on landscapes and its relevance to management and research models', Conserv. Biol., vol. 13, pp. 1282-1292.

Melbourne, BA \& Chesson, P 2005, 'Scaling up population dynamics: integrating theory and data', Oecologia, vol. 145, no. 2, pp. 179-187.

Millennium Ecosystem Assessment 2003, Ecosystems and Human Well-Being: A Framework For Assessment, Millennium Ecosystem Assessment Series. Island Press.

Müller, F 1998, 'Gradients in ecological systems', Ecological Modelling, vol. 108, pp. 3-21.

Müller, J-P, Ratzé, C, Gillet, F \& Stoffel, K 2011, Modeling And Simulating Hierarchies Using An Agent-Based Approach, MODSIM 2011. Available from: <http://www.mssanz.org. $\mathrm{au} />$ [2012.04.02].

Müller, F, Hoffmann-Kroll, R \& Wiggering, H 2000, 'Indicating ecosystem integrity-theoretical concepts and environmental requirements', Ecological Modelling, vol. 130, pp. 13-23.

Naveh, Z 2001, 'Ten major premises for a holistic conception of multifunctional landscapes', Landscape and Urban Planning, vol. 57, pp. 269-284.

Nicolis, G \& Prigogine, I 1989, Exploring complexity: An introduction, Freeman.
Norowi Mohd, H, Perry, JN, Powell, W \& Rennolls, K 2000, 'The effect of spatial scale on the interactions between two weevils and their parasitoid', Ecol. Entomol., vol. 25, pp. 188-196.

O'Neill, RV \& King, AW 1998, 'Homage to St. Michael; or why are there so many books on scale?' in Ecological scale: theory and applications, eds DL Peterson \& VT Parker, Columbia University Press, New York, pp 3-16.

O'Neill, RV, DeAngelis, D, Waide, J \& Allen, TFH 1986, A hierarchical concept of ecosystems, Princeton University Press, Princeton.

Papadimitriou, F 2002, 'Modelling indicators and indices of landscape complexity: an approach using GIS', Ecological Indicators, vol. 2, pp. 17-25.

Peters, DPC \& Havstad KM 2006, 'Nonlinear dynamics in arid and semi-arid systems: Interactions among drivers and processes across scales', Journal of Arid Environments, vol. 65, pp. 196-206.

Peterson, GD 2000, 'Scaling ecological dynamics: selforganization, hierarchical structure, and ecological resilience', Climatic Change, vol. 44, pp. 291-309.

Peterson, DL \& Parker, VT (eds) 1998, Ecological scale: theory and methods, Columbia Univ. Press, pp. 289-307.

Pickett, STA 1989, 'Space-for-Time Substitution as an Alternative to Long-Term Studies', in Long-term studies in ecology. Approaches and alternatives, ed GE Likens, SpringerVerlag, New York Inc., USA, pp. 110-135.

Pickup, G, Chewings, VH \& Nelson, DJ 1993. 'Estimating changes in vegetation cover over time in arid rangelands using Landsat MSS data', Remote Sens. Environ., vol. 43, pp. 243-263.

Pietrzak, M 2009, 'Aktualne i nieaktualne problemy ekologii krajobrazu' [Current and outdated problems of landscape ecology], The Problems of Landscape Ecology, vol. 23, pp. $11-18$.

Powell, DC 2000, Potential vegetation, disturbance, plant succession, and other aspects of forest ecology, U.S. Department of Agriculture, Forest Service.

Reynolds, JF \& Wu, J 1999, 'Do landscape structural and functional units exist?' in Integrating Hydrology, Ecosystem Dynamics, and Biogeochemistry in Complex Landscapes, eds JD Tenhunen \& P Kabat, John Wiley \& Sons Ltd.

Richling, A 1992, Kompleksowa geografia fizyczna [Complex physical geography], Wyd. Nauk. PWN, Warszawa.

Richling, A (ed) 1993, Metody szczegółowych badań geografii fizycznej [Methods of detailed studies of physical geography], PWN, Warszawa.

Richling, A 2004, 'Systemy przyrodniczego podziału przestrzeni' [The systems of natural delimitation of space], The Problems of Landscape Ecology, vol. 14, pp. 17-22.

Richling, A\& Lechnio, J (eds) 2005, Z problematykifunkcjonowania krajobrazów nizinnych [On the problems of functioning of the lowland landscapes], WGSR UW, Warszawa.

Richling, A \& Lechnio, J 2005, Koncepcja krajobrazu - operatory i indykatory ewolucji systemów przyrodniczych [Conception of the landscape - drivers and indicators of systems evolution] in Z problematyki funkcjonowania krajobrazów nizinnych [On the problems of functioning of the lowland landscapes], eds A Richling \& J Lechnio, WGSR UW, Warszawa.

Richling, A \& Solon, J 2011, Ekologia krajobrazu [Landscape Ecology], Wyd. Naukowe PWN, Warszawa.

Schneider ED \& Kay, JJ 1994, Life as a manifestation of the second law of thermodynamics, Mathl. Comput. Modeling, vol. 19, no 6-8, pp. 25-48.

Schneider, DC 2001, 'The Rise of the Concept of Scale in Ecology', BioScience, vol. 51, no. 7, pp. 545-553. 
Solon, J 2009, 'O potrzebie standaryzacji badań ekologicznokrajobrazowych dla celów praktycznych' [About the need for standardization of landscape-ecological research for practical purposes], The problems of landscape Ecology, vol. 23, pp. 19-28.

Steele, JH 1991, 'Can ecological theory cross the land-sea boundary?', Journal of Theoretical Biology, vol. 153, pp. 425-436.

Steinhardt, U \& Volk, M 2003, 'Meso-scale landscape analysis based on landscape balance investigations: problems and hierarchical approaches for their resolution', Ecological Modelling, vol. 168, pp. 251-265.

Strayer, DL, Power, ME, Fagan, WF, Pickett, STA \& Belnap J 2003, 'A classification of ecological boundaries', BioScience, vol. 53, pp. 723-729.

Tallis, HT, Ricketts, T, Guerry, AD, Wood, SA, Sharp, R, Nelson, E, Ennaanay, D,Wolny, S, Olwero, N, Vigerstol, K, Pennington, D, Mendoza, G, Aukema, J, Foster, J, Forrest, J, Cameron, D, Arkema, K, Lonsdorf, E, Kennedy, C, Verutes, G, Kim, CK, Guannel, G, Papenfus, M, Toft, J, Marsik, M, Bernhardt, J, Griffin, R, Głowiński, K, Chaumont, N, Perelman, A \& Lacayo, M 2013, InVEST 2.5.6 User's guide. The natural capital project, Stanford.

Turner, MG, Gardner, RH \& O'Neill, RV 1995, 'Ecological Dynamics at Broad Scales. Ecosystem and Landscapes', BioScience, vol. 45, Supplement: science and biodiversity policy, pp. 29-35.

Turner, MG 1989, 'Landscape ecology: the effect of pattern on process', Annual Review of Ecology Evolution System, vol. 20, pp. 171- 197.

Turner, MG 2005, 'Landscape ecology: what is the state of the science?', Annual Review of Ecology Evolution System, vol. 36, pp. 319-344.

Urban, DL, O'Neill, RV \& Shugart, HH Jr 1987, 'Landscape ecology. A hierarchical perspective can help scientists understand spatial patterns', Bioscience, vol. 37, no. 2, pp. 119-127.

Uuemaa, E, Roosaare, J, Kanal, A \& Mander, Ü 2008, 'Spatial correlograms of soil cover as an indicator of landscape heterogeneity', Ecological Indicators, vol. 8, pp. 783-794.
Viktorov, AS, 1998, Matematicheskaya morfologiya landshafta (Mathematical Morphology of Landscape), Moscow, TRATEK.

Walz, U 2011, 'Landscape Structure, landscape metrics and biodiversity', Living Rev. Landscape Res., vol. 5, no. 3. Available from: <http://www.livingreviews.org//rlr-2011-3> [20.01.2012].

Wheatley, M \& Johnson, C, 2009, 'Factors limiting our understanding of ecological scale', Ecological Complexity, vol. 6 , no. 2, pp. 150-159.

Wiens, JA 1989, 'Spatial scaling in ecology', Functional Ecology, vol. 3, no. 4, pp. 385-397.

Wilbanks, TJ \& Kates, RW 1999, 'Global change in local places: How scale matters', Climatic Change, vol. 43, no. 3 , pp 601-628.

Wolfram, S 1984, 'Cellular automata as models of complexity', Nature, vol. 311, pp. 419-424.

Wu, J 1999, 'Hierarchy and scaling: extrapolating information along a scaling ladder', Canadian Journal of Remote Sensing, vol. 25 , no. 4 , pp. 367-380.

Wu, J 2004, 'Effects of changing scale on landscape pattern analysis: scaling relations', Landscape Ecology, vol. 19, no. 2, pp. $125-138$.

Wu, J \& David, JL 2002, 'A spatially explicit hierarchical approach to modeling complex ecological systems: theory and applications', Ecological Modelling, vol. 153, pp. 7-26.

Wu, J \& Marceau, D 2002, 'Modeling complex ecological systems: an introduction', Ecological Modelling, vol. 153, pp. 1-6.

Wu, JA \& Ye, Q 2000, 'Dealing with scale in landscape analysis: An overview', Geographic Information Sciences, vol. 6, no. 1, pp.1-5.

Wu, J \& David, JL 2002, 'A spatially explicit hierarchical approach to modeling complex ecological systems: theory and applications', Ecological Modelling, vol. 153, pp. 7-26.

Yarrow, MM \& Salthe, SN 2008, 'Ecological boundaries in the context of hierarchy theory', BioSystems, vol. 92, pp. 233244. 